IRA-International Journal of Education \& Multidisciplinary Studies ISSN 2455-2526; Vol.07, Issue 02 (2017) Pg. no. 166-173

Institute of Research Advances http://research-advances.org/index.php/IJEMS

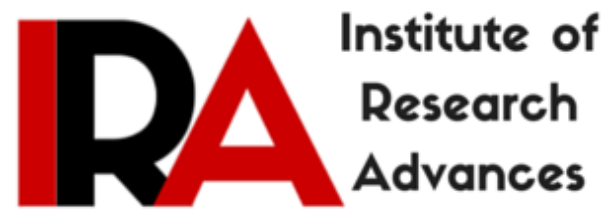

\title{
Work Motivation among Secondary School Teachers
}

Dr. Aneet Kumar

Associate Professor \& Dean, University Institute of Education, SBBS University, Khiala, Jalandhar, Punjab, India- 144030.

Type of Review: Peer Reviewed.

DOI: http://dx.doi.org/10.21013/jems.v7.n2.p13

\section{How to cite this paper:}

Kumar, A. (2017). Work Motivation among Secondary School Teachers. IRA International Journal of Education and Multidisciplinary Studies (ISSN 2455-2526), 7(2), 166-173. doi:http://dx.doi.org/10.21013/jems.v7.n2.p13

\section{(C) Author.}

\section{(cc) BY-NC}

This work is licensed under a Creative Commons Attribution-Non Commercial 4.0 International License subject to proper citation to the publication source of the work.

Disclaimer: The scholarly papers as reviewed and published by the Institute of Research Advances (IRA) are the views and opinions of their respective authors and are not the views or opinions of the IRA. The IRA disclaims of any harm or loss caused due to the published content to any party. 


\section{ABSTRACT}

The purpose of the study was to explore the work motivation among secondary school teachers. The table revealed that $23.67 \%$ secondary school teachers have low level of work motivation, $47 \%$ secondary school teachers have average level of work motivation and $29.33 \%$ secondary school teachers have high level of work motivation. $20 \%$ female teachers have low level of work motivation, $48 \%$ female teachers have average level of work motivation and $32 \%$ female secondary school teachers have high level of work motivation. Similarly $27.33 \%$ male secondary school teachers have low level of work motivation, $46 \%$ male secondary school teachers have average level of work motivation and $26.67 \%$ male secondary school teachers have high level of work motivation. 12\% government secondary school teachers have low level of work motivation, $49.33 \%$ government secondary school teachers have average level of work motivation and $16 \%$ government secondary school teachers have high level of work motivation. Similarly $35.33 \%$ private secondary school teachers have low level of work motivation, $44.67 \%$ private secondary school teachers have average level of work motivation and $20 \%$ private secondary school teachers have high level of work motivation. There was no significant difference in the work motivation of male and female secondary school teachers. There was significant difference in the work motivation of government and private secondary school teachers.

Key Words:Work Motivation, Secondary School Teachers

\section{Introduction}

Work motivation is a set of active forces that originate within and beyond an individual's being, to initiate work-related behavior and to determine its form, direction, intensity and duration. Motivation can be used as a tool to help predict behavior; it varies from person to person and sometimes combined with ability and environmental factors to improve the behavior as well as performance. Work motivation helps a person to increase his performance level and willingness towards a task. It is important for any organizations to understand and to create a healthy work environment to encourage productive and enthusiastic behaviors. It can be done with the help of right motivation strategies. Three psychological processes are concerned with work motivation: arousal, direction, and intensity. Arousal is provocation, which is stimulated by individual's necessities. Direction is the way; a person follows in achieving the aims. Intensity is the amount of energy an individual put into task performance. Motivation can help the employees to focus on particular task. It encourages them to put best of their abilities. Motivation prevent one from deviating from the goal-seeking behavior and results in task strategies. Mitchell \& Daniels, define it as- patterns of behavior produced to reach a particular goal, in their study measurement in universities-implications for work motivation revealed that performance measurement is based on quantitative rather than qualitative measures. The current management by results system has a negative effect on work motivation. In the light of the findings of the study it revealed that management by results is in conflict with intrinsic motivation. Sylvia (1985) examined the need patterns of public school teachers which are essential for the motivations with consideration to teacher awareness of pay equity with relation to intrinsic work elements, work autonomy and satisfaction of higher order needs. The investigator found that teacher motivation is based on the achievement of proper responsibility levels, freedom to try new ideas and inherent work elements. On the bases of results, it was concluded that, those institutions which employ trained people, they should apply some schemes i.e. merit pay scheme. Van \& Aline, (1986), conducted a study of administrative communication system, teacher motivation and job satisfaction. The primary purpose was to find out whether there was relation between school communication system, work motivation and job satisfaction. Significant relationship was found between communication satisfaction and job satisfaction. It was suggested that administrators could increase job satisfaction in their schools by increasing communication satisfaction.

Ellis (1988) explored the relationships between characteristics of teaching as an occupation and the internal work motivation of teachers. Findings showed that teachers found their profession as intrinsically motivating, fulfilling, satisfying and as a career to which they could make a life-long 
commitment. Teacher motivation can be supported by restructuring the job of teaching to allow for a greater degree of challenge and a greater outlet for the need to achieve, to advance, and to become selfactualized. Lemons (1988) explored the factors which influence teacher motivation in a selected public school system. It was revealed that intrinsic factors primarily impacted satisfaction while extrinsic factors were most often related to dissatisfaction. However, pay did not have any influence on the motivation of teachers, but assignment of non-teaching task adversely effected the motivation.

Mittal (1989)in a study of teacher motivation to work and its relationship with the organizational climate of the school it was concluded that teachers working in private schools were significantly more motivated to work than their teachers working in government managed school and the genders of the teachers had no significant influence on the teacher's motivation to work. Teachers who perceive less disengagement, less psycho-physical hindrance, more sprite and more humanized thrust dimensions of the school organizational climate, we found to be more work motivated. Hoffman (1989) compared factors which motivate student teachers and professional teachers to teach. The investigator found that the work itself and achievement most strongly motivate both types of teachers to pursue a career in teaching. Recognition, administration, and salary were more important motivational factors to teachers then to student teacher while supervision and work conditions were more important to students in preparation than teachers.

Locke \& Latham (1990) offered a logical, data-based theory of work motivation and job satisfaction. The present theory is a combination of goal setting, expectancy, social-cognitive, attribution, job characteristics, equity and turnover-commitment and is named as high performance cycle. When any member of organization faced difficult goals, it begins. If high challenge was accompanied by high expectancy of success or self-efficacy, high performance results, given that there was: commitment to the goals, feedback, adequate ability and low situational constraints. High performance was achieved through four mechanisms, direction of attention and action, effort, persistence, and the development of task strategies and plans. High performance, if rewarding, leads to job satisfaction, which in turn facilitates commitment to the organization and its goals. The model has implications for joint leadership, selfmanagement and education. Khan (2001) in a study work motivation among teachers and teacher performance in senior secondary schools of Delhi revealed that teachers in government senior secondary schools in general possessed work motivation to same extent and no significance difference was found in the overall work motivation of male and female teachers. Saeed and Muneer (2012) in a study of work motivation of male and female secondary school teachers in Karachi revealed that female teachers were more motivated in their work than male teachers. Gupta, M. and Hehlavat, M. (2013) in their study job satisfaction and work motivation of secondary school teachers in relation to some demographic variables revealed that no significant difference was found in the job satisfaction and work motivation of male and female teachers. There were significant difference among teachers working in government and private schools; more experienced teachers with respect to job satisfaction and work motivation.

\section{Objectives:}

1. Level of work motivation among secondary school teachers.

2. Level of work motivation among male and female secondary school teachers.

3. Level of work motivation among government and private secondary school teachers.

4. To study the difference in work motivation among male and female secondary school teachers.

5. To study the difference in work motivation among government and private secondary school teachers.

\section{Hypothesis:}

1. No significance difference exists in work motivation among male and female secondary school teachers. 
2. No significance difference exists in work motivation among government and private secondary school teachers.

\section{Methodology}

The investigator used descriptive method to conduct the present research. A sample of 300 secondary school teachers was selected for the study. Equal numbers of government-private and malefemale secondary school teachers were selected for the study. For collecting the required information from the subjects, the investigators used Work Motivation Questionnaire by Aggarwal, K.G. (2006). Mean, Percentage, Standard Deviation, Quartile and t-test were used to analyze the data.

\section{Results}

\section{Level of work motivation among secondary school teachers}

In order to explore the level of work motivation among secondary school teachers of Punjab, the investigator used work motivation scale for collecting information from subjects. The scores of the work motivation scale were calculated and divided into three groups according to the norms of the scale i.e. Low Work Motivation Group (LWMG), Average Work Motivation Group (AWMG) and High Work Motivation Group (HWMG). The subjects having less than 89 scores belong to LWMG while subjects having scores between 89-100 falls in AWMG and the subjects having more than 100 scores belong to HWMG. The results pertaining to different levels of work motivation of secondary school teachers have been presented in table-1.

Table-1

Level of Work Motivation among Secondary School Teachers

\begin{tabular}{|c|c|c|}
\hline Levels of work motivation & N (300) & Percentage \\
\hline LWMG & 71 & $23.67 \%$ \\
\hline AWMG & 141 & $47 \%$ \\
\hline HWMG & 88 & $29.33 \%$ \\
\hline
\end{tabular}

The table revealed that $23.67 \%$ secondary school teachers have low level of work motivation, $47 \%$ secondary school teachers have average level of work motivation and $29.33 \%$ secondary school teachers have high level of work motivation. Thus, by exploring the level trend, it can be said that maximum teachers were falling in average level of work motivation.

\section{Level of work motivation among male and female secondary school teachers}

In order to explore the level of work motivation among male and female secondary school teachers of Punjab, the investigator used work motivation questionnaire for collecting information from Male Secondary School Teachers (MSST) and Female Secondary School Teachers (FSST). The scores of the work motivation questionnaire were calculated and divided into three groups according to the norms of the scale i.e. Low Work Motivation Group (LWMG), Average Work Motivation Group (AWMG) and High Work Motivation Group (HWMG). The subjects having less than 89 scores belong to LWMG while subjects having scores between 89-100 falls in AWMG and the subjects having more than 100 scores belong to HWMG. The results pertaining to different levels of work motivation of secondary school teachers have been presented in the table- 2 . 
Table-2

Level of Work Motivation among Male and Female Secondary School Teachers

\begin{tabular}{|c|c|c|c|c|}
\hline \multirow{2}{*}{$\begin{array}{c}\text { Levels of work } \\
\text { motivation }\end{array}$} & \multicolumn{2}{|c|}{ FSST } & \multicolumn{2}{c|}{ MSST } \\
\cline { 2 - 5 } & N (150) & Percentage & N (150) & Percentage \\
\hline LWMG & 30 & $20 \%$ & 41 & $27.33 \%$ \\
\hline AWMG & 72 & $48 \%$ & 69 & $46 \%$ \\
\hline HWMG & 48 & $32 \%$ & 40 & $26.67 \%$ \\
\hline
\end{tabular}

The results revealed that $20 \%$ female teachers have low level of work motivation, $48 \%$ female teachers have average level of work motivation and $32 \%$ female secondary school teachers have high level of work motivation. Similarly $27.33 \%$ male secondary school teachers have low level of work motivation, $46 \%$ male secondary school teachers have average level of work motivation and $26.67 \%$ male secondary school teachers have high level of work motivation.

\section{Level of Work Motivation among Government and Private Secondary School Teachers}

In order to explore the level of work motivation among government and private secondary school teachers of Punjab, the investigator used work motivation scale for collecting information from Government Secondary School Teachers (GSST) and Private Secondary School Teachers (GSST). The scores of the work motivation scale were calculated and divided into three groups according to the norms of the scale i.e. Low Work Motivation Group (LWMG), Average Work Motivation Group (AWMG) and High Work Motivation Group (HWMG). The subjects having less than 89 scores belong to LWMG while subjects having scores between 89-100 falls in AWMG and the subjects having more than 100 scores belong to HWMG. The results pertaining to different levels of work motivation of secondary school teachers have been presented in the table-3.

Table-3

Level of Work Motivation among Government and Private Secondary School Teachers

\begin{tabular}{|c|c|c|c|c|}
\hline \multirow{2}{*}{$\begin{array}{c}\text { Levels of Work } \\
\text { Motivation }\end{array}$} & \multicolumn{2}{|c|}{ GSST } & \multicolumn{2}{c|}{ PSST } \\
\cline { 2 - 5 } & N (150) & Percentage & N(150) & Percentage \\
\hline LWMG & 18 & $12 \%$ & 53 & $35.33 \%$ \\
\hline AWMG & 74 & $49.33 \%$ & 67 & $44.67 \%$ \\
\hline HWMG & 58 & $38.67 \%$ & 30 & $20 \%$ \\
\hline
\end{tabular}

The results revealed that $12 \%$ government secondary school teachers have low level of work motivation, $49.33 \%$ government secondary school teachers have average level of work motivation and $16 \%$ government secondary school teachers have high level of work motivation. Similarly $35.33 \%$ private secondary school teachers have low level of work motivation, $44.67 \%$ private secondary school teachers have average level of work motivation and $20 \%$ private secondary school teachers have high level of work motivation. 


\section{Difference between Male and Female Secondary School Teachers in Work Motivation}

In order to find the difference in work motivation among secondary school teachers of Punjab, the investigator used work motivation questionnaire for collecting information from 300 male and female teachers. Thereafter the scores of the male and female secondary school teachers were tabulated and t-test was applied. The results have been presented in the table 4 .

Table 4

Difference between Male and Female Secondary School Teachers in Work Motivation

\begin{tabular}{|l|c|c|c|l|l|}
\hline Group & N & Mean & SD & t-value & Result \\
\cline { 1 - 4 } FSST & 150 & 96.72 & 10.52 & & \multirow{2}{*}{1.332} \\
\cline { 1 - 4 } MSST & 150 & 95.19 & 9.28 & & Insignificant \\
\hline
\end{tabular}

The table- 4 revealed the mean difference between male and female secondary school teachers in their work motivation. The table value reflects that the mean scores of female secondary school teachers were 96.72 and male secondary school teachers were 95.19 and standard deviation of female teachers were 10.52 and male teachers were 9.28 respectively. The t-value found to be 1.332 which is found to be insignificant at 0.05 level of significance. Therefore the first hypothesis of the study, which was stated that "There exists no significant difference between male and female secondary school teachers in work motivation", was accepted, because there was no significant difference in the work motivation of male and female secondary school teachers. Mittal (1989); Khan (2001); and Gupta, M. \&Hehlavat, M. (2013)in their studies revealed that no significance difference exist in work motivation among male and female secondary teachers. Findings of Mittal (1989); Khan (2001); and Gupta, M. \&Hehlavat, M. (2013) supports the results of present study. Keeping in view the results it can be said that male and female teachers were equally motivated toward their work. Gender was not playing any role in the work motivation of the secondary school teachers. It was due to the sense of responsibility, which was equal in male and female teachers. They were performing the same duties without any discrimination based on gender. Every teacher has professional training, work ethics and orientation, which was a fundamental cause of the equal work motivation between male and female secondary school teachers.

\section{Difference between Government and Private Secondary School Teachers in Work Motivation}

In order to find the difference in work motivation between government and private secondary school teachers of Punjab, the investigator used work motivation scale for collecting information from 300 government and private secondary school teachers. Thereafter the scores of the Government Secondary School Teachers (GSST) and Private Secondary School Teachers (PSST) were tabulated and t-test was applied. The results have been presented in table-5.

Table-5

Difference between Government and Private Secondary School Teachers in Work Motivation

\begin{tabular}{|c|l|l|l|l|l|}
\hline Group & N & Mean & SD & t-value & Result \\
\hline GSST & 150 & 98.42 & 8.98 & 4.426 & Significant \\
\hline
\end{tabular}




\begin{tabular}{|c|l|l|l|l|l|}
\hline PSST & 150 & 93.49 & 10.25 & & \\
\hline
\end{tabular}

** Significant at 0.01 and 0.05 level

The table- 5 revealed that the mean value of government secondary school teachers was turned out to be 98.42 whereas for private secondary school teachers, it was 93.49. The standard deviation for government secondary school teachers was turned out to be 8.98 whereas for private secondary school teachers, it was 10.25 . Then the t-value was calculated as 4.426 , which was found to be significant at 0.01 level of significance. Therefore the fifth hypothesis of the study, which was stated that "There exists no significant difference between government and private secondary school teachers in work motivation", was rejected. The results revealed that there was significant difference in the work motivation of government and private secondary school teachers. Study conducted by Mittal (1989)and Gupta, M. and Hehlavat, M. (2013) concluded that teachers working in private schools were significantly more motivated to work than teachers working in government managed school. The findings of the Mittal (1989) and Gupta, M. and Hehlavat, M. (2013) were not supporting the finding of the present study. The investigator feels that government teachers seem more motivated than private teachers due to job satisfaction, respected salaries and promotion opportunities. In private schools teachers worked in a very controlling environment. They were not getting very good salaries and were lacking in job satisfaction resulting in less work motivation.

\section{References}

6. Aggarwal, K.G. (2006) Work Motivation Questionnaire. National Psychological Corporation, Agra.

7. Balkis, M., Duru, E. (2007) The Evaluation of the Major Characteristics and Aspects of the Procrastination in the Framework of Psychological Counseling and Guidance. Educational Sciences: Theory and Practice, 7 (1)376-385.

8. Clerment, Baranbe and Mildred, Burn. (1994) Teachers Job Satisfaction and Motivation. Journal on Education Educational Research, 36(2)171.

9. Ellis, N.H (1980), Job redesign: can it influence teacher motivation? Paper presented at the annual meeting of the New England educational research organization(Rockport, ME, April 27-29)

10. Gupta, Madhu and Gehlavat Manju (2013) Job Satisfaction and Work Motivation of Secondary School Teachers in Relation to some Demographic Variables: a Comparative study. Journal of Education and Research for Sustainable Development 1 (1), 8-17.

11. Hoffman,M.H. (1989), Comparing Factors Which Motivate Student Teachers and Professional Teachers to Teach, Dissertation Abstracts International, 50(5),1278.

12. Islahi Fatima (2013) A study of Teaching Effectiveness of Secondary School Teachers in Relation towards Information Technology and Work Motivation. Unpublished, Dissertation, Aligarh Muslim University.

13. Kallio and Kallio (2014) Management-by-Results and Performance Measurement in Universities-Implications for Work Motivation. Studies in Higher Education, 39(4) 574-589.

14. Khan W.A. (2001), A study work motivation among teachers and teacher performance in senior secondary schools of Delhi. Indian Educational Abstracts, 4 (1), 77-78.

15. Lemons, T.L (1988), Factors which Influence Teacher Motivation in a Selected School System, Dissertation Abstracts, International, 50/1, 40-A.

16. Locke and Latham (1990) Work Motivation and Satisfaction: Light at the End of the Tunnel. Psychological Science, 1(4) 240- 246.

17. Rashid, Firdoss (2011), Managerial Creativity and Work Motivation of Secondary SchoolTribal Teachers in relation to their Occupational Self Efficacy, an Unpublished M.Phil. Dissertation, Lovely Professional University Phagwara.

18. Saeed, Ahmad and Muneer, Rizwana (2012) Work Motivation of Male and Female Secondary School Teachers in Karachi, Interdisciplinary Journal of Contemporary research in Business, Vol. 4, (6). 
19. Shyder, M. H. (1989) Motivation and Work Satisfaction in a Liberal Arts College faculty, Dissertation Abstracts International, 50(4), 848-A

20. Srivastava S.K. (1985) Relationship between Job Satisfaction and Organizational Climate: Comparative Study of Private and Public Sector" Indian Dissertation Abstracts.14 (1-4)184-187.

21. Sylvia, R. D., \& Hutchinson, T. (1985). What makes Ms. Johnson teach? A study of teacher Motivation. Human Relations. 38, 841- 56. 